\title{
Transformation of the Paradigm of the Economic Entities Development in Digital Economy
}

\author{
SERHIY SHKARLET \\ Rector, the National University "Chernihiv Polytechnic", \\ Chernihiv, 14035, UKRAINE
}

MAKSYM DUBYNA

Department of Finance, Banking and Insurance, National University "Chernihiv Polytechnic", Chernihiv, 14035, UKRAINE

KHRYSTYNA SHTYRKHUN

Department of Finance, Banking and Insurance, National University "Chernihiv Polytechnic", Chernihiv, 14035, UKRAINE

\author{
LIUDMYLA VERBIVSKA \\ Department of Business, Trade and Stock Exchange Operations, \\ Yuriy Fedkovych Chernivtsi National University, \\ Chernivtsi, 58012, UKRAINE
}

\begin{abstract}
Global digitization forces modern enterprises to respond to the rapid changes in the external environment and adapt to it. As a result, existing business models are being transformed in the areas of production, promotion, communication, calculations, interaction with partners and consumers. In this context, there is growing scientific interest in exploring theoretical and practical aspects of the economy digitization and its impact on the peculiarities of the economic entities functioning. Features of functioning of classical and digital economic entities on the basis of criterion approach have been investigated, using the following criteria: factors of production, form of business organization, location of workplace, production outcome, economic processes, connection with on-demand economy, methods of payment, relations with other enterprises, professions enhancing the image of the enterprise, communication method between employees, saving and processing of information, company promotion tools and consumer communication. The main statistical indicators of the digitalization impact on the activity of enterprises in the world and in Ukraine in 2018 have been analyzed. The feasibility of using digital economy tools has been outlined. Advantages and disadvantages of the impact of digital transformation space on the enterprise have been identified.
\end{abstract}

Key-Words: - economic entity, digitization, business model, digital economy, digital marketing, digital enterprise.

Received: December 23, 2019. Revised: May 14, 2020. Accepted: May 29, 2020. Published: June 4, 2020.

\section{Introduction}

Today, under the influence of digitization, the success of a company is measured not by the size of its capital, its many years of existence, but by its level of flexibility to respond to these changes and adapt the business to a new environment. As noted by a group of scientists [4], a modern enterprise is a complex integrated organizational and production system which components are constantly changing, interacting with each other. Achieving these goals in the context of increased competition among enterprises leads to an increase in the volume and complexity of the production processes, analysis, planning, management, internal and external relations with suppliers, intermediaries, etc. [6], [7], [8], [9].

There is a transformation of existing business models in the fields of production, communication, calculations, interaction with partners, promotion of goods and enhancement of the company's image. Therefore, development of the information society and introduction of the latest information and computer technologies in all spheres of economy is determined by one of the priority directions of the state domestic policy [5] and research in this area is extremely relevant.

The paper consists of several sections. In particular, the second section provides a literature review. Materials and methods have been used 
during the research are presented in section three, while section four provides the results and discussion of the research. The last section reflects the conclusion.

\section{Literature review}

Sufficient attention among domestic scientists (Gudz O. E., Kraus N. M., Matveeva N. M., Melnyk S. V., Mykhailova K. V., Rudenko M. V., Shatokhina D. A., Tokmakova I. V.) was devoted to the study of transformational processes of the enterprise management under the influence of the economy digitization. In the scientific works of foreign scientists, in particular Trașcă D. L., et al. [26], considerable attention is paid to the study of the digitization impact on the economic performance of the enterprise (business activity of the enterprise, size of exports). Rauter R., et al. [15] studied the impact of digitization on innovative business models, changing company values, and analyzed the challenges posed by business digitalization. Reichstein C., et al. [16] conducted the research of the digitization impact on the innovation performance, data privacy, mobility and new business models. The above scholars have made a significant contribution to the development of theoretical foundations of digitization; however, there is still a need to systematize features of the economic activity and managing businesses under the influence of digitization. Therefore, investigating the difference between the classic and digital enterprise based on the criterion approach requires more detailed scientific consideration.

The purpose of the article is to study the transformation of economic entities under the impact of the digital economy based on the criterion approach.

\section{Materials and Methods}

Within the research, a variety of general scientific and special economic methods is used. Among general scientific methods, the authors have used methods of observation, analysis and synthesis, induction and deduction. Among special economic methods, the following have been used:

- comparative method (to systematize features of management of classical and digital enterprises on the basis of the criterion approach under the digitization influence);

- graphical visualization method (to represent advantages and disadvantages of the impact of the digital transformation space on the enterprise);
- economic and statistical (to analyze statistical data on the digitization impact on the business activity of the enterprises).

Note that the greatest attention will be paid to the comparative method. The proposed systematization of features of the economic activity and managing businesses under the influence of digitization on the basis of 12 specific criterions will allow us the following:

- to explore comprehensively the difference between the functioning of a classical and digital enterprise;

- to emphasize the importance of implementation of digital tools (including digital marketing);

- to identify the advantages and disadvantages of the impact of digitalization on activities, including business models of enterprises;

- to determine the level of effectiveness of the impact of digitalization on the activities of enterprises.

The analysis is based on the official statistical databases available in open access. Official data of the Forrester International Independent Analytical Company, the International Data Group (IDG) research company, and the Boston Consulting Group are sources of the research findings on the digitization impact on businesses worldwide. Statistical data on the digitization impact on the business activity of Ukrainian enterprises in 2018 is represented based on the data of the State Statistics Service of Ukraine.

\section{Results and Discussion}

Digitization implies significant development of innovative technologies using artificial intelligence, automation processes and digital platforms [18]. Using the Internet, you can save time and money on goods delivery by using rich information flows to streamline and optimize the flow of physical goods in the supply chain [3], Experts of the Boston Consulting Group say that by 2020 , about $25 \%$ of the global economy will be digitized, allowing the state, business and society to function more efficiently [23].

Digitization changes models of the enterprise management and transforms the classic enterprise into digital one - the enterprise that uses the information technology as a competitive advantage in all areas of its activity, changing product chains, consumer relationships and marketing strategies; causes the emergence of new products and innovations; affects the provision of business resources; reduces the cost of organization, management and communication, as well as the cost 
of obtaining, processing and storing information, etc.

The difference between the classic and digital enterprise is presented in Table 1.

Table 1. Difference between the classic and digital enterprise

\begin{tabular}{|c|c|}
\hline Classic enterprise & Digital enterprise \\
\hline \multicolumn{2}{|c|}{1 Production factors } \\
\hline $\begin{array}{l}\text { Labor, capital, land, } \\
\text { entrepreneurial ability }\end{array}$ & Information, science \\
\hline \multicolumn{2}{|c|}{2 Form of business organization } \\
\hline Mostly hired work & $\begin{array}{l}\text { Employment, self- } \\
\text { employment }\end{array}$ \\
\hline \multicolumn{2}{|c|}{3 Workplace } \\
\hline Physical workplace & Digital workplace \\
\hline \multicolumn{2}{|c|}{4 Production output } \\
\hline Goods and services & $\begin{array}{c}\text { Integrated digital } \\
\text { technologies, products } \\
\text { and services }\end{array}$ \\
\hline \multicolumn{2}{|c|}{5 Economic processes } \\
\hline $\begin{array}{l}\text { High-volume } \\
\text { production }\end{array}$ & Individual approach \\
\hline \multicolumn{2}{|c|}{6 On-demand interaction with economy } \\
\hline $\begin{array}{l}\text { Limited access to } \\
\text { goods and services }\end{array}$ & $\begin{array}{c}\text { Free access to goods and } \\
\text { services }\end{array}$ \\
\hline \multicolumn{2}{|c|}{7 Methods of settlements } \\
\hline $\begin{array}{c}\text { Cash, bank and } \\
\text { traditional financial } \\
\text { institutions }\end{array}$ & $\begin{array}{l}\text { Non-cash settlement, } \\
\text { digital services, } \\
\text { blockchain }\end{array}$ \\
\hline \multicolumn{2}{|c|}{8 Relations with other enterprises } \\
\hline Competition & Coopetition \\
\hline \multicolumn{2}{|c|}{$\begin{array}{c}9 \text { Professions to enhance the image of the } \\
\text { enterprise }\end{array}$} \\
\hline Classical professions & Digital professions \\
\hline \multicolumn{2}{|c|}{$\begin{array}{c}10 \text { Method of communication between } \\
\text { employees }\end{array}$} \\
\hline $\begin{array}{c}\text { Email, } \\
\text { personal } \\
\text { communication, } \\
\text { telephone } \\
\text { communication }\end{array}$ & $\begin{array}{c}\text { Email, } \\
\text { messengers Viber, } \\
\text { Telegram, WhatsApp, } \\
\text { Skype, Zoom, Whereby, } \\
\text { Discord }\end{array}$ \\
\hline \multicolumn{2}{|c|}{11 Saving and processing of information } \\
\hline $\begin{array}{l}\text { EOM computer } \\
\text { software, paper } \\
\text { medium }\end{array}$ & $\begin{array}{l}\text { Electronic media, cloud } \\
\text { storage and cloud } \\
\text { computing }\end{array}$ \\
\hline \multicolumn{2}{|c|}{$\begin{array}{l}12 \text { Tools for promoting the company and } \\
\text { communicating with consumers }\end{array}$} \\
\hline $\begin{array}{c}\text { Personal } \\
\text { communication, } \\
\text { classic marketing } \\
\text { and Public Relations }\end{array}$ & $\begin{array}{l}\text { Digital marketing and } \\
\text { digital infrastructure }\end{array}$ \\
\hline
\end{tabular}

Sources: compiled by the authors
1. Production factors. Rapid development of the digital economy is associated with widespread use of digital-information and communication technologies that have been able to transform a traditional resource-consuming economy into a resource-creating economy. Therefore, the emphasis on traditional factors of production (labor, capital, land and entrepreneurship) has shifted to information (electronic and virtual data), providing electronic communications with electronic devices, tools and systems) and science (availability of certain necessary knowledge, skills, individual competencies of the employee, such as talents, creativity, experience, etc.), and ways to access them). With the development of science and technology, physical work has been transformed into brainwork. In addition, experts predict that in the future, all tasks will be completed by robots. Capital is no longer a determining factor in starting your own business; now you can do it with minimal investment. Land has ceased to be a major factor in production, as new types of products (devices) that do not need it have emerged. Entrepreneurial capabilities (i.e., strategies for purely economic effect - profit) are no longer working in pure form, instead, businesses are investing in social projects, which are first and foremost beneficial to the population (provide useful information, the services you need for free, and usually with environmental concerns), thus providing social and environmental effects that can eventually create an economic impact for the company. For example, one company that has been operating in the market for a long time is ready to invest in the implementation of a specific social action project, acting only as a sponsor of the project. If the project is useful and gains popularity, the sponsoring company's rating can automatically rise and increase the number of its clients. It is much easier for digital enterprises than traditional businesses to find co-organizers, volunteers, material suppliers to implement such projects, and invite a target audience for the event.

2. Form of business organization. As a result of the society digitization, there is a tendency to increase the number of self-employed persons, including those engaged in entrepreneurship. At the same time, one person can be the business owner, the manager, and the executor of all stages of the company's operation. Internet development provides unlimited opportunities for e-business (business services, online sales, etc.), and this means that business processes are carried out instantly anywhere and in any direction. The purpose of this virtual organizational form of business is to ensure competition for scarce resources and finance to meet 
customer needs as quickly as possible [20,21]. This form of employment significantly reduces the cost of starting and running a business; significantly reduces time for communication with consumers; does not depend on the location of the consumer; gives the opportunity to cooperate with other specialists; reduces significantly the cost of premises, because many types of economic activity can be carried out from home; allows you to plan and organize your working hours independently; accelerates order fulfillment [1].

3. Workplace. Transition to the digital economy is accompanied by a change in the workplace from physical (office, enterprise) to digital. Generally, the term "digital workplace" was coined by Charles Grentem and Larry Nichols back in 1993. It is generally accepted that a digital workplace is the virtual equivalent of a physical workplace, which requires proper organization, use and management, because it should be the key to improving employees' efficiency and creating more favorable working conditions for them. "The digital workplace does not require a permanent employee to be in one specific place and involves the use of information, technology, processes and collaboration tools between company employees to work on any device and at any time [2]. Nowadays, the hub management model, which implies that the company has many employees who work remotely, even from different parts of the world, but are fully involved in the team and workflow and, if necessary, can take any vacancy in the office, is extremely popular.

Benefits of this way of labor organization are increase of the work efficiency, creation of more favorable working conditions, provision of a flexible working environment with appropriate digital tools, technologies and access to digital infrastructures. As this method of labor organization is extremely attractive, it allows having a positive impact on the employment market and promotes retention of skilled workers, increased tax revenues and social insurance contributions.

4. Production outcomes. Analysts say that by 2020, half of goods and services in consumer markets will be innovative and automated, and concepts such as "smart city", "smart home", "smart car", "smart clothing" and so on will be used in everyday life.

To date, businesses are already leveraging a range of integrated digital technologies, products and services, such as BioTech, NanoTech, RetailTech, FinTech, LegalTech, InsurTech, GovTech, BlockChain, to increase staff efficiency, conserve resources and increase profits. Digital marketing, CRM \& BPM on bpm'online platform,
Grid technology, Digital insurance, ePrescription, TeleHealth, etc. [12]. In addition, development of big data, the Internet of things, cloud computing, predictive analytics, and more, is in the future.

5. Economic processes. They are characterized by the transition from the production of goods and the provision of services for mass consumption to the individual approach to each potential consumer. Customers can even order products on their own sketches. For example, if a business representative goes to an advertising agency to develop the material they need, they can adjust it by talking to the designer online.

6. On-demand interaction with economy. In today's environment, any consumer can place an order from home, pay by bankcard online and receive its order. Thus, benefits of an on-demand economy for consumers are quick access to the required product or service, lower cost of goods or services due to fewer intermediaries, for businesses - getting orders online and completing orders offline, which simplifies communication with customers and significantly reduces time spent [25].

One successful example is the Spanish fast delivery service for anything (supermarket, restaurant, cafe, pharmacy, etc.) via the Glovo mobile app. In Ukraine, Glovo appeared in 2018, and despite that quickly gained popularity. Thus, development of this service in Ukraine compared to other European countries was the highest in terms of execution of 100 thousand orders per month. Thanks to this service, Glovo-affiliated companies can save on gasoline costs and staff salaries, which can deliver food from the company itself.

7. Methods of settlements. Under to the opinion of Gudz O.Ye., "increasing the number of users of digital services from 5 million in 2016 to 15 million in 2021 will allow $95 \%$ of all shops, salons, services to make payments without cash. This will reduce the cost of printing paper money and help put the economy out of the shadows. Labor productivity and income of the population will increase. The level of corruption will be significantly reduced as the vast majority of transactions will take place electronically and automatically across multiple registers" [10].

In the digital economy, functions of banks and traditional financial institutions are gradually being replaced by the new organizational structure of the business - blockchain, which is a block chain system. With this method of settlements, financial transactions are anonymous and secure. With this method of settlement, financial transactions are anonymous and secure. The seller and the buyer are participants in the financial business, and the miner 
is a kind of intermediary. Each has its own virtual wallet and key. The advantage of blockchain is decentralization, so thanks to its collective use; this system allows payments to move quickly and openly in the global space, it creates responsibility, trust and transparency for all participants in the process [14].

8. Interaction with other enterprises. One element of digitization is the combination of different technologies in new ways, as opposed to the classic, already outdated way of simply disseminating information technology. As a result, companies are changing their forms and methods of doing business and are able to deliver innovative products in both existing and new market segments.

With the digitization development, there is a gradual change in the forms of business cooperation from competition to coopetition. Thus, former competitors can easily become partners by pooling their efforts on digital platforms and sharing them. The term coopetition (from English terms "cooperation" and "competition") was first used in the 1980s by Ray Nord, the founder and CEO of American IT Corporation Novell. Coopetition makes possible share resources instead of competing duplicates, which is observed by competition; learning valuable partners' know-how and skills while protecting own core competency or advantage; reduction costs, risks and uncertainties associated with innovation or new product development during global expansion; build better customer relationships because companies that, on the one hand, compete in the market by offering different products and services, and on the other, by working together to improve their productivity and quality of goods and services, giving customers greater customer value than if they were sold by one company [19].

For example, one business may lack the capital, some business knowledge and customer base in a particular area, and another may have all that. At the same time, another company may need specialists who have digital skills to work with clients and is able to respond quickly to their demand. Therefore, in this case, enterprises can pool their resources in order to implement jointly innovative projects.

However, in these circumstances, a new phenomenon emerges as a competitive breakthrough, due to the rapid development of startups and emergence of young professionals with innovative ideas and products, who have access to global digital platforms for research and hands-on digital marketing, high-speed sales and distribution skills that businesses may lack.
9. Professions to enhance the image of the enterprise. Digitization can create more than 400,000 new jobs in Ukraine [10]. For example, professions involved in creating the image of the enterprise and promoting its products (marketer, PR manager) are replaced by new ones, which are already in high demand: SMM Manager, SEO Specialist, Brand Manager, Project Manager, Event Manager, Community Manager, Video Blogger, Content Manager, Mobile Marketer, Web Analyst, Information Security Manager, and more. Companies may have the required specialists in their staff, however, at present, the lack of skilled digital professionals is a major problem for businesses. Therefore, there is a need to persistently recruit, retain, develop and improve digital skills of the available staff. Another solution to this problem is to pay for the services of digital agencies that can help to enhance the image of the company, promote its products and services through the digital environment.

In addition, an extremely important component for a modern enterprise is the creation and rapid implementation of effective projects, as opposed to the routine activities of classic enterprises. This requires continuous staff training through trainings, master classes, workshops and online webinars.

10. Method of communication between employees. Rapid development of technologies has influenced the change of methods of information transfer between employees from personal communication, phone calls; email has become increasingly used in daily life. In addition, the need to save time caused the emergence of such messengers as Viber, Telegram, WhatsApp. In order to address important issues they conduct online meetings via Skype (audio, video, and web conferencing).

It is worth noting the widespread use of specialized software to optimize internal communication, in particular, ERP, electronic document management, CRM, BMPS, UPE performance management platform [10].

11. Saving and processing of information. Initially, there was a transition from storing the necessary data on paper to storing information on the hard disk of a personal computer. However, today this is not enough because of the enormous amount of information and the need for more efficient processing and use.

In today's context, engagement with colleagues and partners implies an increase in the level of the information openness. Therefore, network approach, storing information on remote servers or in the cloud is widely used. Advantages of this storage 
method include as follows: secure storage and efficient data management, efficient use of resources, increased ability to solve complex business problems, improving the quality of products, services and servicing, the ability to increase the amount of information storage if needed [10].

Unlike the traditional method of working with software, which involves performing various operations and calculations using programs, that are installed on the computer, cloud computing services are applications that are accessed via the Internet through a browser. Advantages of this approach are that cloud computing services are equipped with new features, which simplify the process of work and allow the processing of a large amount of information; the user is not attached to its place of work and can use any computer with Internet access to complete the tasks; processed information is protected against computer malfunction; this reduces the cost of maintaining and upgrading the software on your computer; allows you to share easily and quickly the results of work with colleagues and even work together.

According to the State Statistics Service of Ukraine, in Ukraine, in 2018, businesses that had access to the Internet used it for sending or receiving email (98.7\%); banking operations (97.2\%); receiving information on goods and services $(88.8 \%)$; receiving information from public authorities (80.9\%); transactions with state authorities (except for receiving information) (51.8\%); use of instant messaging and electronic bulletin board $(48.9 \%)$; access to other financial services $(40.7 \%)$; making phone calls via Internet / VoIP or video conferencing (31.6\%).

12. Tools for promoting the company and communicating with consumers. The classic enterprise uses personal communication and tools of classic marketing and Public Relations such as exhibitions, fairs, advertising on television, radio, billboards, newspapers, magazines, flyers and more. At the same time, digitization does not include these tools, but takes them to a new level of development that is more accessible to everyone, the online level to promote your business and its products and services. Thus, if you include a QR code on your billboard that you can use to access the company website, then it is a digital marketing tool [13]. In addition, digital marketing tools include the following ones: Google Adwords Contextual Advertising, Yandex Direct, Mobile Marketing; email, social media marketing (SMM), social network optimization (SMO), search engine optimization (SEO), etc. [17].
Interactivity (direct interaction of the consumer with the company); absence of territorial restrictions by the implementation of marketing ideas; easy access to the resource; the ability to find and quickly reach your target audience; effectiveness evaluation of the company's activities should be related to the advantages of digital marketing.

In addition, effectiveness of traditional marketing activities is measured primarily by the statistics that take some time to elapse between advertising campaigns and consumer responses [17]. In contrast, the advantage of digital media is that this gap is narrowed several times because statistics are received in real time (the number of times a post was viewed, the number of people who liked it, comments of users, and the ability to conduct polls and get quick answers).

The modern enterprise actively uses e-mail, Instagram mobile applications, Telegram, Facebook social network, blogging, vlogging, community development in social networks to invite a potential client to the same offline event (exhibition, fair, seminar, etc.). According to Forrester, an international independent analytics comp any, email is the most common customer service channel, as $54 \%$ of respondents used email to contact The Forrester in 2018 [24].

In 2018, a quarter of Ukrainian businesses used social media to promote their products, $18.7 \%$ cooperated with their business partners and $18.3 \%$ of enterprises maintained communication with their existing and potential customers (Table 2), which confirms the widespread use of social media for doing business effectively.

Table 2. Purpose of the use of social media by enterprises in 2018

\begin{tabular}{|c|l|c|}
\hline & \multicolumn{1}{|c|}{ Indicator } & $\begin{array}{c}\text { Value, } \\
\%\end{array}$ \\
\hline 1 & $\begin{array}{l}\text { Presentation of the enterprise / } \\
\text { advertising of its goods, works and } \\
\text { services) }\end{array}$ & 25.1 \\
\hline 2 & $\begin{array}{l}\text { Cooperation with business } \\
\text { partners / other organizations }\end{array}$ & 18.7 \\
\hline 3 & $\begin{array}{l}\text { Receiving customer feedback / } \\
\text { answering their questions }\end{array}$ & 18.3 \\
\hline 4 & Hiring workers & 13.9 \\
\hline 5 & $\begin{array}{l}\text { Exchange of views, opinions } \\
\text { knowledge within the enterprise }\end{array}$ & 12.4 \\
\hline 6 & $\begin{array}{l}\text { Involvement of clients in the } \\
\text { development / innovation of goods } \\
\text { and services }\end{array}$ & 11.6 \\
\hline
\end{tabular}

Sources: compiled by the authors based on the data of State Statistics Service of Ukraine [22] 
On the other hand, only $13.9 \%$ of enterprises hired employees, $12.4 \%$ used social media to exchange views / knowledge within the enterprise and $11.6 \%$ - to engage customers in the development / innovation of goods and services [22].

In addition, creating communities on social networks and mobile apps has become an effective way to reach potential customers, since, in this case, the content of the community is created not only by specialists, but also by existing consumers of the goods or services of the company, who leave their reviews, photos, videos and other materials about the products and can be important for potential clients of the enterprise [13].

An extremely effective tool for advertising both the enterprise as a whole and the goods and services it sells is blogging and vlogging by the employees of the enterprise, sometimes businesses even pay for the services of popular bloggers as thought leaders to promote and discuss the product. This tool is particularly in demand among teenagers and young people, and far outstrips cable TV.

In addition, the company website is also one of the tools of communication and customer engagement; however, the purpose of creating a corporate site with a traditional enterprise and a digital one is different. Previously, the task of the site was to inform consumers about the company and its products, now - personal communication with customers, gathering contacts of potential consumers and the ability to order goods online.

Thus, the use of digital tools gives unrestricted access to product catalogs for Internet users, which greatly reduces the time to search for necessary goods and services, allows you to make the purchase decisions and reduce the risk of buying a substandard product based on the experience and feedback of other users of the product, and allows businesses to influence effectively, emotionally and psychologically their target audience, enables them to examine promptly the consumer demand and respond to it based on the wishes of customers and business partners.

So, in this article, we note the importance of the use of the instruments of digital marketing to meet the demands of a new world. Digital marketing helps to create better interaction between an economic entity and its target audience through special instruments, in particular, the internet (YouTube, social media, other applications, or web pages) or search engines (SEO, SEM).

In 2018, the International Data Group (IDG) conducted a survey of 702 organizations across industries, including technology, financial services, legal services, manufacturing, education, health, public service, telecommunications and utilities, retail and wholesale, and distribution who have already digitized their business or are just planning to do so. According to the survey, $38 \%$ of traditional businesses have adopted a digital business strategy in 2018. In addition, the main indicators of the digitization impact on business activity in 2018 are shown in Table 3.

Table 3. Key indicators of the digitization influence the business activity in 2018

\begin{tabular}{|c|l|c|}
\hline & \multicolumn{1}{|c|}{ Features } & $\begin{array}{c}\text { Share of } \\
\text { enterprises, } \\
\text { \% }\end{array}$ \\
\hline 1 & $\begin{array}{l}\text { Increasing } \\
\text { productivity by automating } \\
\text { processes }\end{array}$ & 58 \\
\hline 2 & Innovations introduction & 57 \\
\hline 3 & $\begin{array}{l}\text { Increasing customer } \\
\text { satisfaction }\end{array}$ & 52 \\
\hline 4 & $\begin{array}{l}\text { Improving business } \\
\text { performance through } \\
\text { employees' data sharing }\end{array}$ & 49 \\
\hline 5 & Achieving high growth rates & 46 \\
\hline 6 & Increase in revenue & 35 \\
\hline 7 & $\begin{array}{l}\text { Improving the data } \\
\text { management strategy }\end{array}$ \\
\hline
\end{tabular}

Sources: compiled by the authors based on the data of International Data Group [11]

In particular, more than half of enterprises due to the transition to digital technologies increased employee productivity by automating processes $(58 \%)$, introduced innovations $(57 \%)$, increased customer satisfaction (52\%). In addition, $35 \%$ of enterprises surveyed increased their revenues by $35 \%$, which is an extremely important indicator for enterprises. Thus, the above data indicate the positive impact of digitalization and business development, however, there are also some risks and disadvantages to the impact of the digital transformation space on the enterprise, which has been systematized and reflected in Figure 1. 


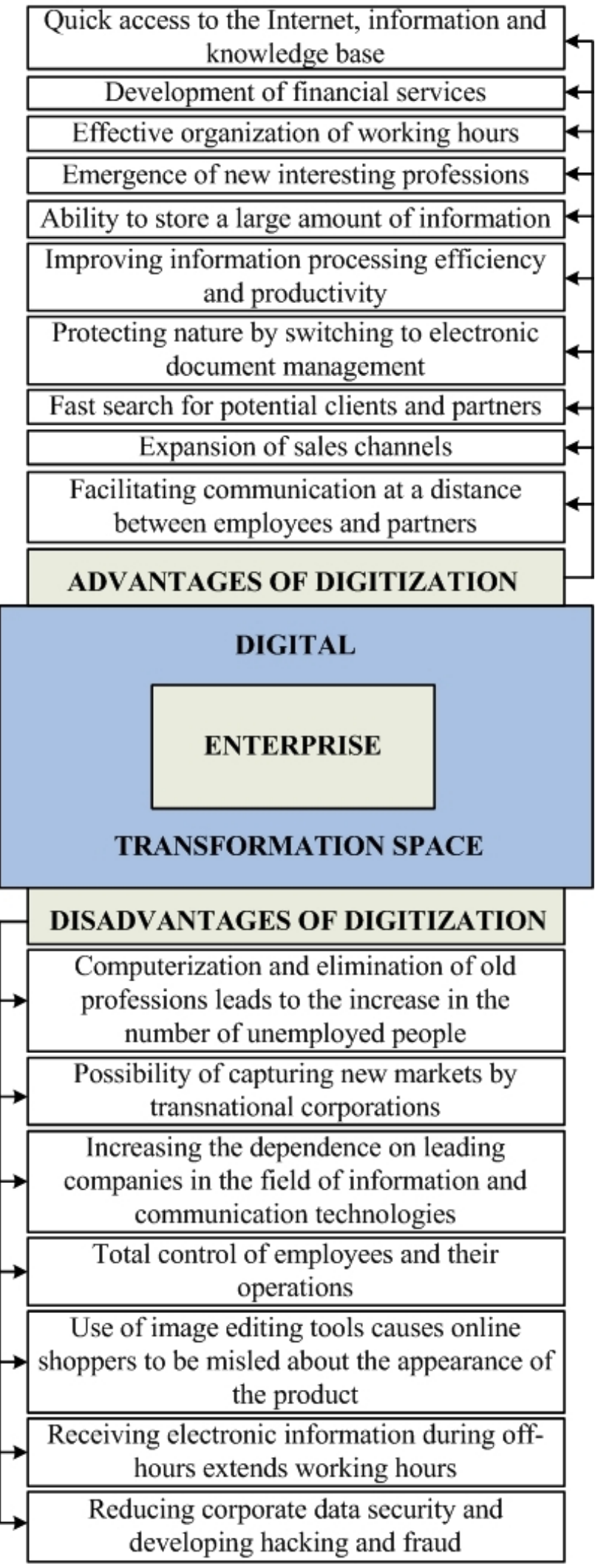

Figure 1. Advantages and disadvantages of the impact of digital transformation space on the enterprise

Sources: compiled by the authors

\section{Conclusion}

Thus, digitization has a positive effect on transformation processes in the activities of economic entities. In particular, digitization results in significant savings in financial resources, increase of the activity efficiency of both the individual employee and the activity of the enterprise as a whole, improving communication with consumers and significant development of on-demand economy, development of financial services, efficient organization of working hours, emergence of new interesting professions, i.e. new jobs, increase of labor productivity, expansion of sales channels of products, etc.

On the other hand, there are some risks and disadvantages posed by digitalization for businesses: elimination of old professions leads to an increase in the number of unemployed, increasing dependence on leading companies in the field of information and communication technologies, total control of employees and their operations, reducing corporate data security and development of hacking and fraud, etc.

Expanding the use of blockchain and cryptocurrency for payments with consumers and suppliers; creation of business portals for placing orders and offers; creation of innovative forms of investment, crediting and insurance; investing in new technologies such as artificial intelligence, business intelligence and the best digital asset management software solutions should be related to the main directions of the digital economy development.

It should be noted, this paper is mostly focused on the investigation of the difference between the classic and digital enterprise under the influence of the digital economy based on the criterion approach and reflects the advantages and disadvantages of the impact of digital transformation space on the enterprise. Therefore, in the framework of the further research, there is a need to analyze in more detail the impact of the transformation of traditional enterprises into digital ones and the results of this transformation (in particular, on the example of a specific enterprise that was able to adapt to requirements of the digital economy and began to use digital technologies).

\section{References:}

[1] Andrianova, V.V. Rozvytok samozainiatosti naselennia yak shliakh vyrishennia problemy zainiatosti [Development of self-employment as a way of solving the problem of employment]. Kultura narodov Prichernomoria - The Culture of the Black Sea 
Peoples, Vol. 262, 2013, pp. 10-13 [in Ukrainian].

[2] Attaran, Mohsen \& Attaran, Sharmin \& Kirkland, Diane. The Need for Digital Workplace: Increasing Workforce Productivity in the Information Age. International Journal of Enterprise Information Systems. Vol. 15, 2019, pp. 2-15.

[3] Babenko, V., Kulczyk, Z., Perevozova, I., Syniavska, O., Davydova, O. Factors of Development of International e-Commerce in the Context of Globalization. CEUR Workshop Proceedings, vol. 2422, 2019, pp. 345-356. URL: http://ceur-ws.org/Vol-2422/paper28.pdf

[4] Babenko, V., Romanenkov, Yu., Yakymova, L., Nakisko A. Development of the model of minimax adaptive management of innovative processes at an enterprise with consideration of risks. Eastern-European Journal of Enterprise Technologies, Vol 5, No 4 (89), 2017, pp. 4956.

[5] Bilovodska, O., Gaidabrus, N., Ruban, D. An analytical study on logistics outsourcing impact on logistical service quality in supply chains (case study: industrial enterprises of Sumy region). Problems and Perspectives in Management, 15(3), 2017, pp. 201-211. http://10.21511/ppm.15(3-1).2017.04.

[6] Bilovodska, O., Gryshchenko, O., Syhyda, L. The marketing channel structure: A case of chemical industry company. Periodicals of Engineering and Natural Sciences, 7 (2), 2019, pp.

$741-751$. http://dx.doi.org/10.21533/pen.v7i2.556.

[7] Bilovodska, O., Gryshchenko, O., Syhyda, L. Specific features of regional logistics potential consideration in the process of the enterprise distribution system development. Economic Annals-XXI, 160(7-8), 2016, pp. 105-110. https://doi.org/10.21003/ea.V160-21.

[8] Chmutova, I. \& Vovk, V. \& Bezrodna, O. Analytical tools to implement integrated bank financial management technologies. Economic Annals-XXI, Vol. 163(1-2(1)), 2017, pp. 95-99. URL: $\quad$ http://soskin.info/ea/2017/163-1-21/201726.html

[9] Gudz, O.E. Tsyfrova ekonomika: zmina tsinnostei ta oriientyriv upravlinnia pidpryiemstvamy [Digital Economy: changing values and guidelines of the enterprise management]. Ekonomika. Menedzhment. Biznes - Economy. Management. Business, Vol. 2, 2018, pp. 4-12. URL: http://nbuv.gov.ua/UJRN/ecmebi_2018_2_3 [in Ukrainian].
[10] Hrabovskyi, Y., Babenko, V., Al'boschiy, O., Gerasimenko, V. (2020). Development of a Technology for Automation of Work with Sources of Information on the Internet. WSEAS Transactions on Business and Economics, Vol. 17, Art. \#25, pp. 231-240. doi: 10.37394/23207.2020.17.25International Data Group. URL: https://www.idg.com

[11] Kraus, N. M., Goloborodko, O. P. and Kraus, K. M. Digital economy: trends and perspectives of the abangard change of development, Efektyvna ekonomika, [Online], Vol. $1, \quad 2018 . \quad$ URL: http://www.economy.nayka.com.ua/?op=1\&z= 6047

[12] Kuznetsov, A., Kavun, S., Smirnov, O., Babenko, V., Nakisko, O., Kuznetsova, K. (2019). Malware Correlation Monitoring in Computer Networks of Promising Smart Grids. 2019 IEEE 6th International Conference on Energy Smart Systems, ESS 2019 - Proceedings, No. 8764228, pp. 347352. doi: 10.1109/ESS.2019.8764228

[13] Marchuk, O.O. Tsyfrovyi marketynh yak innovatsiinyi instrument upravlinnia [Digital marketing as an innovative management tool]. Ekonomika i suspilstvo - Economy and Society, Vol. 17, 2018, pp. 296-299 [in Ukrainian].

[14] Mykhailova, K.V. \& Matveeva, N.M. Tsyfrova transformatsiia ta yii vplyv na biznes ta dilove seredovyshche [Digital transformation and its impact on business and business area]. Mizhnarodnyi naukovyi zhurnal "Internauka" International Scientific Journal "Internauka", Vol. 20, 2018. URL: https://www.internauka.com/uploads/public/15438237831447.pd $\mathrm{f}$ [in Ukrainian].

[15] Rachinger, Michael \& Rauter, Romana \& Ropposch, Christiana \& Vorraber, Wolfgang \& Schirgi, Eva. Digitalization and its influence on business model innovation. Journal of Manufacturing Technology Management, 2018, pp. 1143- 1160.

[16] Reichstein, C., Harting, R.-C., Neumaier, P. Understanding the Potential Value of Digitization for Quantitative Research Results of European Experts. In Agents and MultiAgent Systems: Technologies and Applications 2018. Proceedings of the 12th International Conference on Agents and Multi-Agent Systems: Technologies and Applications (KESAMSTA-18), 2018, pp. 287-298.

[17] Ruban, V.V. Tsyfrovyi marketynh: rol ta osoblyvosti vykorystannia [Digital marketing: the role and features of use]. Ekonomichnyi visnyk Zaporizkoi derzhavnoi inzhenernoi 
akademii - Economic Bulletin of Zaporizhzhya State Engineering Academy, Vol. 2(2), 2017, pp. 20-25. URL: http://nbuv.gov.ua/UJRN/evzdia_2017_2\%282 $\% 29 \quad 5$ [in Ukrainian].

[18] Rudenko, M. V. Tsyfrovizatsiia ekonomiky: novi mozhlyvosti ta perspektyvy [Digitalization of economy: new opportunities and perspectives]. Ekonomika ta derzhava Economy and State, Vol. 11, 2018, pp. 61-65 [in Ukrainian].

[19] Rudny W. Coopetition as a new way of structuring interorganizational relations. Studia Ekonomiczne. Zeszyty Naukowe Uniwersytetu Ekonomicznego w Katowicach, Vol. 224, 2015, pp. 199-208.

[20] Shkarlet, S. \& Dubyna M. \& Hrubliak O., \& Zhavoronok, A. Theoretical and applied provisions of the research of the state budget deficit in the countries of Central and Eastern Europe. Administratie si Management Public, Vol. 32, 2019, pp. 120-138.

[21] Shkarlet, S. \& Kholiavko, N., \& Dubyna, M. Territorial reform in the system of strategic management of energy-economic and information spheres of the state. Economic Annals-XXI, Vol. 5-6, 2015, pp. 103-107.

[22] State Statistics Service of Ukraine. URL: http://www.ukrstat.gov.ua

[23] The Boston Consulting Group. URL: https://www.bcg.com

[24] The Forrester - International Independent Analytical Company. URL: https://www.forrester.com

[25] Tokmakova, I. V. \& Shatokhina, D. A. \& Melnyk, S.V. Stratehichne upravlinnia rozvytkom pidpryiemstv $\mathrm{v}$ umovakh tsyfrovizatsii ekonomiky [Strategic management of enterprise development in conditions of digitalization of the economy]. Visnyk ekonomiky transportu i promyslovosti Bulletin of Economics of Transport and Industry, Vol. 64, 2018, pp. 283-291. URL: http://nbuv.gov.ua/UJRN/Vetp_2018_64_41.

[26] Trașcă, D. L., Ştefan, G. M., Sahlian, D. N., Hoinaru, R., \& Şerban-Oprescu, G.-L. Digitalization and Business Activity. The Struggle to Catch Up in CEE Countries. Sustainability, Vol. 11(8), 2019 